
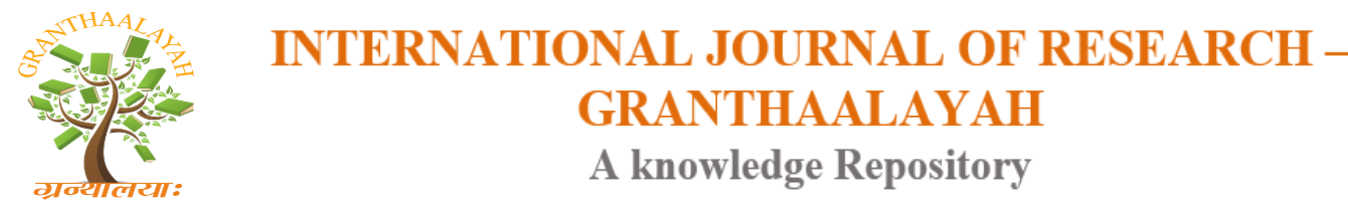

Social

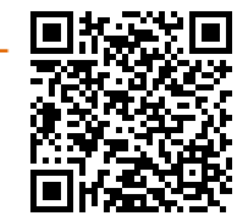

\title{
SOCIAL ENTREPRENEURSHIP: CHALLENGES IN WAY TO RISE
}

\author{
Seema Devi *1 \\ ${ }^{* 1}$ PhD Research Scholar, IMSAR, MDU, Rohtak, INDIA
}

DOI: https://doi.org/10.29121/granthaalayah.v4.i9.2016.2552

\section{ABSTRACT}

Social entrepreneurship is the use of the techniques by startup companies and other entrepreneurs to develop, fund and implement solutions to social, cultural, or environmental issues. This concept may be applied to a variety of organizations with different sizes, aims, and beliefs. For-profit entrepreneurs typically measure performance using business metrics like profit, revenues and increases in stock prices, but social entrepreneurs are either non-profits or blend for-profit goals with generating a positive "return to society" and therefore must use different metrics. Social entrepreneurship typically attempts to further broad social, cultural, and environmental goals often associated with the voluntary sector in areas such as poverty alleviation, health care and community development. This article builds on the literature to define social entrepreneurship, discusses the boundaries of sociallyoriented entrepreneurial activities, and positions the social entrepreneur in the spectrum of entrepreneurship.

Keywords:

Social Entrepreneurship; Startup; Non- Profit; Socially-Oriented Entrepreneurial Activities.

Cite This Article: Seema Devi, "SOCIAL ENTREPRENEURSHIP: CHALLENGES IN WAY TO RISE” International Journal of Research - Granthaalayah, Vol. 4, No. 9 (2016): 191-197.

\section{INTRODUCTION}

The economic development of a nation is depends upon its industrial growth rate. The industrial development requires entrepreneurial competencies among people. An entrepreneur is an innovator, who implements entrepreneurial change within markets, where entrepreneurial have five manifestations i) the introduction of new/developed goods ii) the introduction of new methods of production iii) the opening of new market iv) the exploitation of source of supply v) the carry out of new organization of any industry. (Schumpeter,1934). Thus, an entrepreneur is innovative, highly motivated and a critical thinker. When these attributes are used to solve social problems, a social entrepreneur is born. The social entrepreneurs are ambitious and persistent, tackling major social issues and offering new ideas for wide scale change rather leaving societal needs to the government or business sectors. Social entrepreneurs always focuses on what is not working and finding out the solution by changing the system and influencing the whole society 
to move in different directions. The term "Social Entrepreneur" and "Social entrepreneurship", firstly, used in 1960s and 1970s for social change. But it is adopted on a large scale in the 1980s and 1990s, promoted by Bill Drayton the founder of Ashoka: Innovators for the Public (Austin, Stevenson, Skillern, 2006) and others such as Charles Leadbeater. Social entrepreneurs identify the social problems like nutrition, education and health care, unemployment, illiteracy and by helping them provide a worthwhile life. Social entrepreneurship is next big thing that influence India as the country juggles to achieve a balance between a growing GDP, ensuring sustainable growth and attempting to address issues ranging from education, energy efficiency to climate change.

In India, social entrepreneur is a person, who can be the founder, co-founder or a chief functionary (may be president, secretary, treasurer, chief executive officer (CEO), or chairman) of a social enterprise, or a Non-Profit, which raises funds through some services (often fund raising events and community activities) and occasionally products. Today, non-profits and nongovernmental organizations, foundations, governments, and individuals also play a critical role to establish, promote, fund, and advise social entrepreneurs around the world. A growing number of educational institutions are organizing programs focusing on education and training of social entrepreneurs.

Social entrepreneurship is the field in which entrepreneur's ultimate goal is to create social value by improving the standard of living and take care of quality of life. Social entrepreneurship can be for profit or non-profit organisations. Probably, these arise out of the strong social mission that generates structure promotion to re-think the traditional models and conceptualize new hybrid business models.

\section{LITERATURE REVIEW}

Social entrepreneurship is attracting the attention all over the world from the past few decades. The scope of social work is no longer limited to activism. Today, there are many opportunities in child welfare, community policing, healthcare, counselling etc. in not only NGO's but also national and international bodies as well as social enterprises. The global efforts of Ashoka, founded by Bill Drayton in 1980, provide a seed funding to entrepreneurs with a social vision (http://www.ashoka.org); the multiple activities of Grameen Bank, rooted by Professor Muhammad Yunus in 1976 to reduce poverty and empowering women in Bangladesh (http://www.grameen-info.org); or the use of arts to develop community programs in Pittsburgh by the Manchester Craftsmen's Guild, founded by Bill Strickland in 1968 (http://www.manchesterguild.org): these are contemporary manifestations of a phenomenon that finds its historical precedents in, among other things, the values of Victorian Liberalism. The conviction of "enlightened entrepreneurs", as some Victorian industrialists are referred to, that there was a need to link commercial success with social progress, gave birth to industrial groups used in economic wealth for the good of the community (Bradley, 1987; Thompson, Alvy, \& Lees, 2000). While entrepreneurial phenomena aimed at economic development have received a great amount of scholarly attention (Busenitz, West III, Sheperd, Nelson, Chandler, \& Zacharakis (2003) for a review of the empirical and theoretical development of the entrepreneurship concept), entrepreneurship as a process to foster social progress has only presently getting the interest of researchers (Alvord, Brown, \& Letts, 2004; Boschee, 1995; Dees 
and Elias, 1998; Thompson, 2002). The development of social entrepreneurship as an area for research closely resembles the development of research on entrepreneurship itself. Williams (1999) argued that interest in entrepreneurship as a field of study was crucially stimulated by community leaders' belief that entrepreneurship was a defining trend of the 21 st century. Similarly, we observe that the rise of scholarly interest in social entrepreneurship goes side by side with a growing interest in the paradox among society. Over the past few decades, a number of successful business entrepreneurs have dedicated substantial resources to supporting social entrepreneurship. For example, Jeff Skoll, cofounder of eBay, created a foundation and donated 4.4 million pounds to establish a research center for social entrepreneurship (http://www.skollfoundation.org). Jeff Bezos, founder of Amazon, announced a one million US dollar award for innovative approaches and breakthrough solutions to effectively improve communities or the world at large (http://www.amazon.com). Social entrepreneurs join the leaders of nations and corporations in panel discussions at the World Economic Forum in Davos (http://www.weforum.org).

\section{OBJECTIVES}

Objectives of the study are:

1) To study the concept and meaning of social entrepreneurship.

2) To identify the role and importance of social entrepreneurship in India.

3) To know the challenges faced by social entrepreneurs.

\section{SOCIAL ENTREPRENEURSHIP}

Social entrepreneurship generally defined as -Entrepreneurship activity with an embedded social purpose. It is a process of come out with innovative solutions to social problems. More specifically, social entrepreneurs adopt a social vision to transform the society by creating and sustaining social values. They relentlessly pursue opportunities to serve this mission, while continuously adapting and learning. They draw attention and induce them to think in both the business and nonprofit worlds to operate in all kinds of organizations: large and small; new and old; religious and secular; nonprofit, for-profit, and hybrid. There is nothing as powerful as a new idea in the hands of a first-class entrepreneur. Social entrepreneurs often seem to be possessed by their ideas, committing their lives to changing the direction of society. They are not only visionaries, but also realists, and have passion or power to convert dreams into reality.

The Social Entrepreneurship Initiative (SEI) based at Stanford University has developed a model on social enterprise that reflects the diversity of social entrepreneurs. They describe that social enterprises can be: as for-profit organizations which use their resources to creatively address social issues with earning some money; as not- for- profit organizations which help individuals establish their own small without considering profit, for- profit businesses, or not-for-profit organisations which create or increase economic value to fund their own programs or to create employment and training opportunities for their client population. (Eleanor and Carter, 2004)

Social Entrepreneurship can't be defined accurately. But it can be taken as-Social entrepreneurship is the work of a social entrepreneur. A social entrepreneur is someone who recognizes a social problem and uses entrepreneurial principles to organize, create, and manage a 
venture to make social change. Whereas a business entrepreneur typically measures performance in profit and return, a social entrepreneur assesses success in terms of the impact s/he has on society.

There are 3 key components that emerge out of this definition and are more or less common when it comes to the other variations of the definition of Social Entrepreneurship:

1) The problem

2) A sustainable solution

3) Social change

On the basis of above components, the social entrepreneurs find out their focus areas, matching with mission. Social entrepreneurs advance innovations that:

1) Tracking gradual deforestation using policy, market and community-driven mechanisms.

2) Provide employment opportunity by enhancing a person's ability and personal dignity through training and development programme.

3) Tackle assistance that to be more accountable, transparent and solutions-oriented, for long lasting development.

4) Provide the means to access and ensure the uses in reliable, affordable and appropriate healthcare for disadvantaged populations.

5) Address issues of sustainable productivity not beneficiary by beneficiary, but system wide.

6) Build the foundation nuts and bolt for peace and human security.

7) Harness the capital and consumer markets that drive change by considering all costs and opportunities.

\section{IMPORTANCE OF SOCIAL ENTREPRENEURSHIP IN INDIA}

Social entrepreneurs always recognize the new opportunities and serve as a game changer. They adopt a mission to create and sustain social value by relentlessly pursuing new opportunities with continuous innovation, adaptation, and learning, acting boldly without being limited resources, currently, in hand, makes clear a heightened sense of accountability to the constituencies served and for the outcomes created.

The Importance of Social Entrepreneurship for Development:

1. Employment Development: The social entrepreneurship creates hefty employment opportunities in ballpark figure, it is from $1 \%-7 \%$ of people employed in non-profit oraganisation. To continue, in the case of "Grameen Bank" the economic situation of six million disadvantaged women micro-entrepreneurs were improved.

2. Innovation in Services: The biggest issues like HIV, mental ill-health, illiteracy, crime and drug abuse are confronted in innovative ways. An example showing that these new approaches in some cases are transferable to the public sector is the Brazilian social entrepreneur Veronica Khosa, who developed a home-based care model for AIDS patients which later changed government health policy. 
3. Social Capital: Social entrepreneurs play a front-page role in generating social capital. Examples are the success of the German and Japanese economies, which have their roots in longterm relationships and the ethics of cooperation, in both essential innovation and industrial development. The World Bank also pays attention to social capital as nit-picking for poverty mitigation and sustainable human and economic development. Investments in social capital can start a virtuous cycle.

4. Equity Promotion: Social entrepreneurship cultivates a more equitable and ethical society by identifying social issues and trying to accomplish open-ended sustainable impact through their social mission in a certain degree, than purely profit-maximization. In Yunus's example, the Grameen Bank supports handicapped women. Another case is from the American, the social entrepreneur J.B. Schramm who helped thousands of low-income high-school students to get into tertiary education.

To put in a nutshell, social enterprises should be appraised of as a positive force, as change agents, fixing up leading-edge innovation to unmet social needs. Social entrepreneurship is not a catholicon as it works within overall social and economic framework, but problems should be resolved at grassroots, or starts from the ground level, which is often neglected. This deserves much more attention from academic theorists as well as policy makers. This is expressly important in developing countries like India where welfare states, facing increasing financial stress.

\section{CHALLENGES FOR SOCIAL ENTREPRENEURS}

1. Lack of support by Government: The majority of social entrepreneurs yet to recognize themselves as a legitimate field of endeavor. This recognition is the sine qua non for finding ways to call attention through fiscal and legislative incentives, in addition to the review of tax laws, the reducing over burden of regulations, arbitrary decision-making and other troublesome requirements and inefficient practices those creel social entrepreneurs.

2. Indian traditional education system: As education provide base for promoting entrepreneurship in the business sector but India, is still encumbered by the traditional educational system. By seeing its growing demand entrepreneurship education is a "new cup of tea" especially to graduates of business schools and management institutes, whereas for students of other streams like the sciences and arts it is a blue pencil. Because of this disparity in the Indian education system the country's entrepreneurial sector is still immature and struggling.

3. Deficiency of financial assistant: From a financial perspective, approaching the fresh market social entrepreneurs require funding for designing, implementing and refining innovative ways of bringing previously excluded groups into the marketplace. The best and brightest talent demand for a handsome salary and stock options as a reward of their hard work. So, I become very difficult for non-profit organizations to pay a large amount from their own funds or by raising funds from local money lenders at a high rate of interest.

4. Changing environment: After introduction of LPG in 1991, the flood gates of technology have been opened to all, simultaneously, the government policies are changing with changing 
global prospective. Now, the organisations need to be better equipped to respond to the challenges of the 21 st century. They should embrace technological, political risk as a key opportunity for global renewal, and make it a priority to spot and legitimize those who have the capacity to imagine and the ability to implement what they imagine through disciplined innovation.

5. Out of pocket work: The solution to various societal problems and welfare of the society carries a cost, which is mostly borne by the owner out of their own pocket or by taking loans from money lenders. Social entrepreneurs are not, as a matter of course, working in a moneymaking market; they identify a problem within society and try to find cost effective solutions for them. Once they find the way to earn some profit after providing the best low cost solution to the needs of the society, more traditional businesses will enter the market competing with a similar solution and technique, increasing transaction costs and competition for social entrepreneurs and hampering their future growth.

6. Domination by wealthy founders and philanthropists: The challenge for social entrepreneurs relates to foundations and philanthropists who should be the ones catalyzing social transformation by supporting the social innovators. Foundations and high net worth individuals are certainly well placed to engage in that process, as they are free of two forces that dominate the decisions of governments and business respectively.

7. Lack of Skilled Manpower: Social enterprises feel necessity for competent workforce volunteers, labourers and community participants to make parallel the long term growth motives. But social enterprises needs training and development programme as they are typically employ from the underprivileged sector of the society. The organizations have to attempt to fulfil the aspirations of all these divergent groups and still come out with the best results.

8. Social and Cultural Effect: In India, the social and cultural perception of social entrepreneurship sometimes becomes a challenge for social entrepreneurs in running their business activities. As in the case of Water Health International, the major focus of this social venture was to awaken the people about various water diseases and how they can be cured, but people were still sceptical about how, and why, WHI is providing the purified water at such a low cost. This impression shows the lack of knowledge or foresightedness of the local community in distinguishing a social business from a normal profit-driven business.

\section{CONCLUSIONS AND RECOMMENDATIONS}

The Indian economy has been marked accelerated growth since past few decades. But dismally, the social, economic and environmental problems are multiplying year after year which necessitates the extensive application of multidisciplinary approaches and entrepreneurial energy in all sectors. As discussed earlier, India is permitting an increase in social entrepreneurship and attempts by social entrepreneurs to find economical solutions to various sections of society. The changes in technological and political environment hike the competition so; social entrepreneurs have to become more dynamic and creatives. Some suggestions for Indian social entrepreneurs in achieving their objectives are as under: 
1) Social entrepreneurs should motivate education institutes to develop curriculum that inculcate social entrepreneurship habits in their students.

2) Social ventures should educate and aware the society about set market standards by following network approach. This may increase demand for their goods and services.

3) The Regional disparities or imbalance should be reduced by the growth of social entrepreneurship as balancing growth can solve the social problem of large population and health of the country.

\section{REFERENCES}

[1] ADB (2009). Asian Development Bank Study on "Institutions And Governance In The Poverty Response" Poverty in the Philippines: Causes, Constraints And Opportunities, 2009 pp-51.

[2] Austin, J., Stevenson, H., \& Wei-Skillern, J.(2003). Social Entrepreneurship And Commercial Entrepreneurship: Same, different, or both?. Harvard Business Review pp.04-029.

[3] Austin, Stevenson \& Wei-Skillern J 2006, Social and Commercial Entrepreneurship; same or different both Entrepreneurship theory \& practice 30 (1):1-22

[4] Chakraborty, S.K. (1987), Managerial Effectiveness And Quality of Worklife: Indian Insights, New Delhi, Tata McGraw-Hill Publishing Co. Ltd.pp.169.

[5] Christie, M. J., \& Honig, B. (2006). Social Entrepreneurship: New Research Findings. Journal of WorldBusiness, pp 1-5, 44.

[6] Dees and Anderson (2006), "Framing a Theory of Social Entrepreneurship: Building on Two Schools of Practice and Thought," in Research on Social Entrepreneurship: Understanding and Contributing to an Emerging Field, Association for Research on Non-profit Organizations and Voluntary Action (ARNOVA), 2006.

[7] Frumkin, P. (2002). Social Entrepreneurship On Being Nonprofits. Cambridge, Mass.: Harvard University Press pp.129-162.

[8] Gupta, R. (2001) "Creating Indian Entrepreneurs. India Today", organizations in India. "Participatory Research in Asia" (PRIA)(2002), 167-195.

[9] Schumpeter, J. (1934), The Theory of Economic Development. Cambridge, MA: Harvard University Press.

[10] Pacific Business Review, Referred Quarterly Journal, Vol. 2, April - June,2010.

[11] http://www.ashoka.org

[12] http://www.grameen-info.org

[13] http://www.manchesterguild.org

[14] http://www.skollfoundation.org

[15] http://www.amazon.com

[16] http://www.weforum.org 